\title{
Sustainable development and strategic transport management in the Øresund region
}

\author{
S. L. Jeppesen \& S. Leleur \\ Centre of Traffic and Transport, \\ Technical University of Denmark, Denmark
}

\begin{abstract}
Traffic planning has developed over the years and has produced both long-term and short-termed solutions of different kinds. In general, however, in many urban and regional areas, traffic planning has until now not been able to treat and resolve the increasing problems relating to uncurbed traffic growth. Therefore new planning strategies and approaches are needed. In addition, the quality of transport networks and other types of traffic infrastructure are becoming more and more important features for metropols and regions when competing in attracting investment, development and knowledge. This is especially relevant for a cross-boarder region as the Øresund region treated in this paper. To ensure a sustainable development while at the same time upgrading the quality of urban and reginal transport is thus a major challenge. To deal with this situation the paper outlines a wider approach to sustainable regional transport planning. This is done by setting up a so-called holistic approach to planning and afterwards, based on holistic planning, by presenting the ideas of Strategic Transport Management (STM) as an important new planning and management concept. Finally some conclusions are given together with a perspective.
\end{abstract}

Keywords: the Øresund region, Global Metropole Competition (GMC), holistic planning, Strategic Transport Management (STM), transport planning, transport systems.

\section{Introduction}

The Øresund region consists of areas in both Denmark and Sweden. The area covers both a core area and a periphery. The core can be considered as Copenhagen and Malmo, and the periphery is then the rest of the region. The region is 
centrally located in between the Nordic countries and the European mainland. The connections between Oslo, Stockholm, Copenhagen, Malmo, Hamburg and Berlin are called the Scandinavian Cross and indicate that lines of connection between the major Nordic cities all pass right through the Øresund region [1]. Thereby Copenhagen and Malmo become the natural centre of the region. This position offers both the core and the periphery a unique possibility in the ongoing competition of attracting investment, knowledge, jobs and activity to the region.

Due to rising competition, metropoles and regions are to keep on providing improved surroundings and options for new activities and enterprises. The Øresund region is bound to attract knowledge-based enterprises, and therefore the transport system needs to be further developed. This necessitates a long term and strategic planning approach.

\section{Sustainable development and holistic planning}

The planning process in Copenhagen has evidently developed a lot over recent decades. During a study of the arguments for planning there has been identified a terminology to describe the different incentives for planning. These incentives have been divided into planning bases and from these different planning methods have been identified as shown in Figure 1.

The planning bases have been identified as need, expectations and possibilities. These are based on the tendencies which it has been possible to identify in Danish planning development going some decades back. Due to the development of traffic and traffic modes and concurrent congestion there is a clear need for action and thus for traffic planning. Expectations are the second of the planning platforms and indicate the prospect stemming from innovative and technological development for both transport means and planning methods. Last but not least are the possibilities. This basis indicates planning which is not directly driven by need or expectations but by identifying what might be possible in the future.

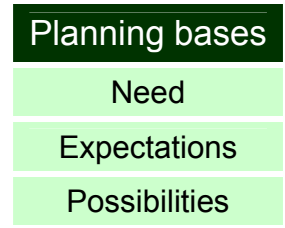

$$
\begin{gathered}
\text { Planning methods } \\
\text { Traditional planning } \\
\text { Future planning } \\
\text { Visionary planning }
\end{gathered}
$$

Figure 1: $\quad$ Planning bases and planning methods.

To define planning on behalf of the planning bases, planning methods will be needed. The three separate planning bases have created a platform for identification of three planning methods. These are: traditional planning, future planning and visionary planning. Each of these planning methods has its separate aim.

The traditional planning method seeks to solve the instant planning need. Therefore this kind of planning has been - and will still be - necessary for traffic 
planning and for planning in other sectors. However this kind of planning will usually be short-sighted and therefore further planning will be needed within often relative short periods. Future planning is an attempt to predict the prospect of the development. This planning method does not try to change the development but tries to make room for it based on predictions and forecasts. This method may rely on calculations and simulations, and though these can be faulty this method does try to set up plans with a long-term perspective. The visionary planning provides planners with the possibility to model an ideal world by introducing new thought patterns and in that way create new solutions.

All of the planning bases and planning methods have been used in the Danish planning of traffic related matters. The planning bases and the planning methods are related to different societal conditions and time periods. Usually the concepts have been used separately, and if used in combination then only two of them at a time. However, the Danish Ministry of Transport in 1993 was the first to use all the concepts in the same study. This report called "Trafik 2005" aimed at producing an overall view of the Danish traffic sector and its goals and possibilities. "Trafik 2005" took all the concepts into consideration, but these were used mainly without interaction [2]. This to some extent weakened the possibilities to make long-term planning.

In Figure 2 on the following page the planning bases are shown in the middle dark green triangular area. This area has been divided into three planning bases. Need and Expectations are placed at the bottom and forms the foundation of Possibilities. Thus Possibilities rely on sound images based on Need and Expectations. The outer and light green triangle indicates that the bases should integrate with each other to make a seamless planning.

In the "Trafik 2005" planning document, the planning bases and the planning methods were used more or less separately. To remedy this, the concept of holistic planning, see Figure 3 next page, has been set out.

Holistic planning intends to produce a framework for an integrated type of planning that take account of all the factors normally treated separately by traditional planning, future planning and visionary planning. Holistic planning is specified by [3]:

"A planning method, where all implied effects are thought of in such a way that all elements are given influence, hereby, a development which takes care of all apparent needs, without preventing future generations' possibilities for reaching their goals, are sought".

Holistic planning thus can help promoting the development and implementation of sustainability in the transport sector. In this paper it functions as the methodological background for the concept of strategic transport management (STM) treated below. 
126 Urban Transport XII: Urban Transport and the Environment in the 21st Century

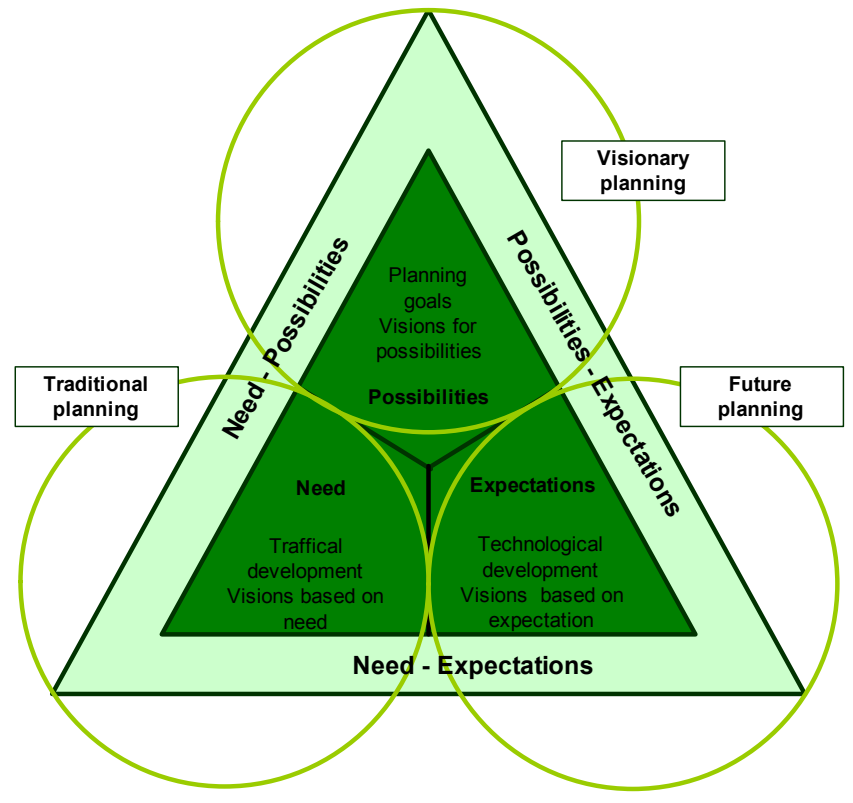

Figure 2: $\quad$ Planning bases and methods in combination.

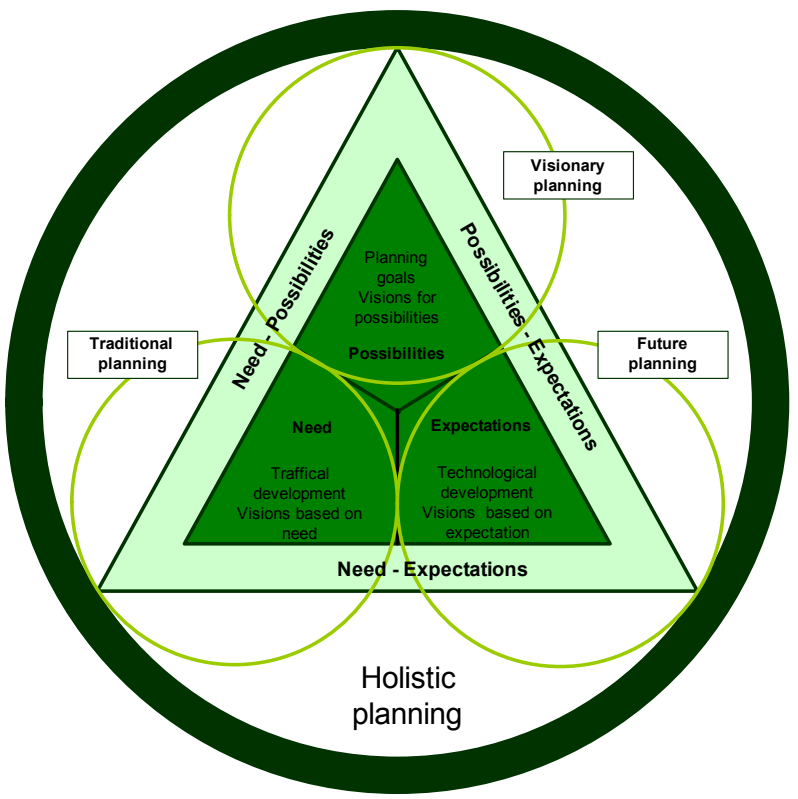

Figure 3: The content of holistic planning. 


\section{Strategic transport management in the Øresund region}

The Øresund region is seen as a region participating in the global metropole and regional competition. This competition is increasing due to the importance of attracting activity, education, investment and jobs to the metropols and regions. To make the Øresund region as attractive as possible a well-functioning transport system is required. To obtain this, highly educated planners and modern traffic planning tools along with political intentions about sustainable development are needed.

One initiative to obtain this is the INTERREG IIIA project called Strategic Transport Management in the Øresund region (STMØ). This project is carried out 2005-2007 by Malmö University, the University of Lund, Copenhagen Business School and the Technical University of Denmark. One of the aims of the STMØ project is to break down barriers of integration in the Øresund region. Another aim is to improve the education of planners and transport professionals.

The project is divided into three phases, where the first phase is just finished and concerns a mapping of barriers in the Øresund region. These barriers can be either physical or non-physical or a combination of both. One important and obvious barrier for Øresund integration was removed in 2000 when the Øresund Fixed Link was opened.

The study objectives of the STMØ project follow from Figure 4 on the following page. The dark green area describes the content of the STMØ project and the two light green areas describe STMØ related areas. The upper light green area indicates subjects which can influence the project and the lower light green area indicates initiatives which are not part of the STMØ project but which can complement the work carried out by STMØ.

The entrance to the STMØ project is a recognition of overall Global Metropole Competition (GMC). This indicates as already indicated that competition among metropoles and regions is becoming even more relevant due to the increasing globalisation. Due to research conducted by The Core Cities Group [4] the following six generic factors of relevance have been identified [5]:

- economic diversity

- a skilled workforce

- connectivity - internal and external

- strategic decision-taking capacity

- innovative firms and organisations

- quality of life

In the STMØ project the focus is especially on the factor of connectivity internal and external. Strategic Transport Management (STM) is developed as a way of dealing with this specific GMC competence. 


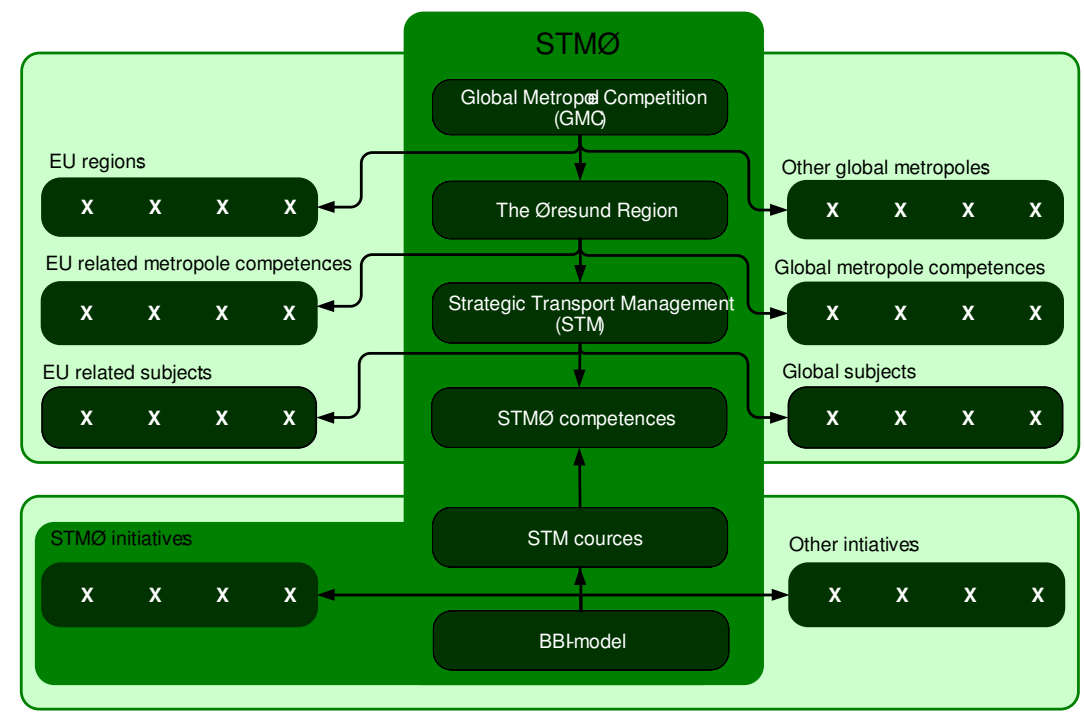

Figure 4: $\quad$ Content of the STMØ project and related areas.

In the STMØ study STM has been identified as a competence in the region that can lead to:

“... a transport system where the quality, expenditure of time and effectiveness of the transport activities under the handling is developed based on holistic and long-term planning, which coordinates all the influencing factors. The transport activities should furthermore be carried out under consideration of both surroundings and the need and possibilities of society..." [6]

It should be noted that to make STM unfold in a satisfactory way a comprehensive type of planning is needed which makes holistic planning relevant.

To define STM more accurately it has been divided into nine different topic issues: Transport logistics, technology, enterprises, transport legislation, transport structures, economy, transport networks, planning and environment. These issues together form the regional STM competence, see Figure 5.

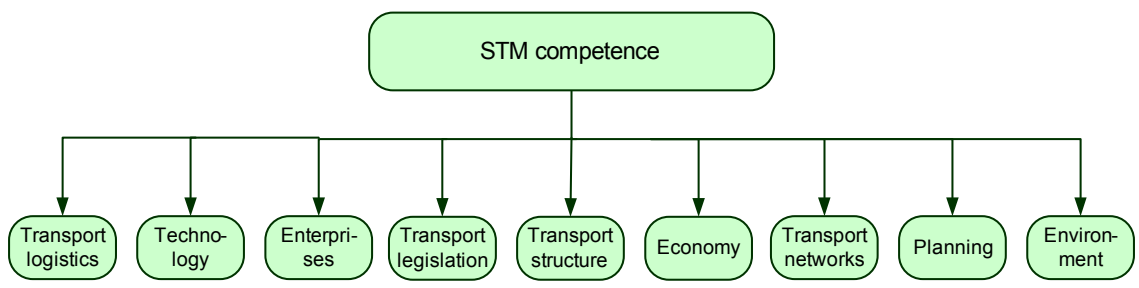

Figure 5: $\quad$ STM competence based on different topic areas. 
The fifth level of Figure 4 indicates that the STMØ project is supposed to develop several initiatives to diminish or remove integration barriers. Among these are educational courses at master level given at the Øresund University in cooperation with the different partners of the STMØ project. This is in due time supposed to form a master in STM, where planners and transport professionals will be educated in STM, holistic planning and the special conditions of the Øresund region.

When all these initiatives have been formulated they will be examined and sorted out by a decision support model, the BBI-model, see the sixth level of Figure 4.

One particular aim of STM is to link private and public competences as in agreement with the holistic planning approach, these all need to be considered. In Figure 6 it is shown how the nine topic areas are split in this respect with a private sector, a public sector and an area in-between [7].

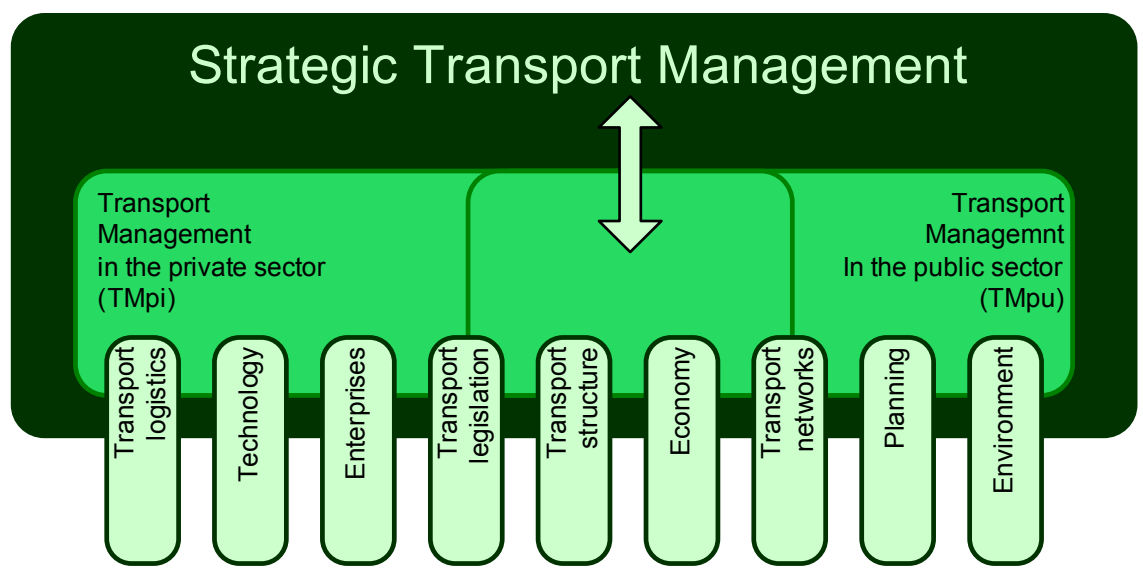

Figure 6: $\quad$ STM and the private and public sectors.

\section{Conclusions and perspective}

Although the STMØ project is not yet finished the results so far from phase 1 2005-2006 indicate that strategic transport management (STM) will constitute a new important planning and management concept. Based on the planning ideas contained in a holistic approach to planning STM can be recognised as one of several competences that will be needed by a metropole/region to establish itself in the ongoing global metropole competition (GMC), with GMC as one of the important issues characterising ongoing globalisation.

With focus on the Øresund region the STMØ project will continue to develop STM with an emphasis on combining and updating planning methodology that can help further cross-border integration and increased possibilities of new development. STM is seen as one of the factors that can ensure a sustainable development of the Øresund region. 


\section{Acknowledgements}

This paper is based on research within the INTERREG IIIA project Strategic Transport Management in the Øresund region (STMØ). The projects has been carried out by Malmö University, the University of Lund, Copenhagen Business School and the Technical University of Denmark, City of Malmö, City of Copenhagen, City of Landskrona, Swedish Maritime Administration, Municipality of Helsingborg, Øresund University and the project is co-financed by the European Union. Comments and inputs from other members of the STMØ team have been highly appreciated and taken into consideration to improve the presentation.

\section{References}

[1] Hovedstadens Udviklings Råd, Trafikplan 2003, HUR, 2003

[2] Trafikministeriet, Trafik 2005 - Problemstillinger, mål og strategier, Trafikministeriet, 1993

[3] Jeppesen, S. L. and Pedersen \& E. S., Regional trafikplanlagning frem mod 2015 - Visioner og metoder med udgangspunkt i Øresundsregionen, Centre of Traffic and Transport, the Technical University of Denmark, 2005

[4] Parkinson, M., Simmie, J., Clark, G. \& Verdonk, H., Competitive Cities: Where do the Core Cities Stand?, Office of the Deputy Prime Minister, 2004

[5] Taylor, S., The Region, The City and The University, AURIL Autumn conference 2005, P. 2, 2005

[6] STMØ, Strategic Transport Management in the Øresund Region, Centre for Traffic and Transport, the Technical University of Denmark, Draft version of phase 1 report 1 Kortlcegning af barrierer i Øresundsregionen med hensyn til: Transportlogistik, teknik, erhverv, transportjura, transportstruktur, Økonomi, Transportnet, planlcegning og miljø, STMØ, 2006

[7] STMØ, Strategic Transport Management in the Øresund Region, Draft version of phase 1 report 5, Kortlcegning af barrierer $i$ Øresundsregionen med hensyn til: Transportnet, planlagning og miljø, Centre for Traffic and Transport, the Technical University of Denmark, 2006. 